\author{
Agnieszka Czyżak \\ Wydział Polonistyki \\ Uniwersytet im. Adama Mickiewicza w Poznaniu \\ e-mail: agnieszkaczy@tlen.pl
}

\title{
W cudzej przestrzeni - narracyjne gesty (samo)poznania w prozie przełomu XX i XXI wieku
}

Przekształcanie cudzej przestrzeni w tekst, tematyzowane jako akt rekonstrukcji miejsc utraconych, zapomnianych, startych z aktualnych map, odsłania z reguły zgoła odmienne przeznaczenie. Przestrzeń kreowana w takich tekstach staje się specyficznym "miejscem autobiograficznym"1 autora, zaanektowanym i zinterioryzowanym $\mathrm{w}$ akcie twórczej ekspresji i autorefleksji. W miejscu poddawanym uważnemu, ale silnie subiektywizowanemu oglądowi, przekształcana wielorako potoczna pamięć przeszłości oraz jej utrwalone $\mathrm{w}$ tradycji wizje współistnieją $\mathrm{z}$ krzyżującymi się na różnych poziomach współczesnymi dyskursami etycznymi, ideologicznymi i artystycznymi. Cywilizacyjna katastrofa, która doprowadziła do gruntownego przeobrażenia znanego nam świata, pozostawiła puste miejsca domagające się wypełnienia, odtworzenia, przede wszystkim zaś podjęcia próby zrozumienia przebiegu minionych zdarzeń i wejścia $\mathrm{w}$ osobistą, osadzoną $\mathrm{w}$ aktualnych realiach, relację z przeszłością - jej śladami, znakami, cieniami.

1 Zob. M. Czermińska, Miejsca autobiograficzne. Propozycja w ramach geopoetyki, „Teksty Drugie" 2011, nr 5, s. 183-200. Badaczka wskazuje, iż miejsce autobiograficzne można dookreślić jako indywidualne miejsca pamięci, którego niezbywalnym atrybutem jest jego jednostkowy wymiar, odniesienie do świadomie wytwarzanej tożsamości. Nadto jest ono: „znaczeniowym, symbolicznym odpowiednikiem autentycznego miejsca geograficznego oraz związanych z nim kulturowych wyobrażeń. Nie istnieje w topograficznej próżni, nie odnosi się do przestrzeni geometrycznej, uniwersalnej i pustej" [tamże, s. 188]. 
Marek Zaleski, przypominając głęboko zakorzenione w świadomości zbiorowej przekonanie, iż „umarli niepogrzebani należycie - wracają” 2 , wskazywał na przyczyny niedostatecznej reprezentacji traumatycznych doświadczeń wojny $\mathrm{w}$ literaturze powstającej $\mathrm{w}$ okresie następującym po jej zakończeniu. Umarli nie mogli znaleźć odpowiedniego miejsca w tekstach, bo silniejszy okazywał się mechanizm zapomnienia służący życiu, wzmacniany przez rzeczników zwycięskiej wówczas ideologii. Utraceni bliscy okazywali się też na rozmaite sposoby „niesłusznymi” umarłymi, o których należało zapominać dla własnego bezpieczeństwa czy choćby spokoju. Przede wszystkim jednak: „umarli nie mogli znaleźć swego miejsca, bo piszący mieli świadomość niewydolności języka i jego wadliwych reprezentacji $\mathrm{w}$ obliczu tego, czym była wojenna i okupacyjna śmierć, szczególnie w swej nowej postaci" ${ }^{3}$.

Istotnym aspektem późniejszego utrzymywania sfer niepamięci w obrazowaniu Zagłady okazał się długo usuwany ze sfery świadomości zbiorowej fakt, iż traumatyczna historia nie wydarzyła się wyłącznie pomiędzy Niemcami i Żydami. Pojawiła się konieczność ponownego utekstowienia przestrzeni, w której rozegrała się tragedia wpisywana odtąd w schemat trójkąta - nierównobocznego, ale jednak o trzech wierzchołkach. Tym samym także podjęcie tematu stawało się $\mathrm{z}$ reguły równoznaczne $\mathrm{z}$ wpisaniem się autora $\mathrm{w}$ ramy jednego z wielu współistniejących, jednak coraz bardziej sprzecznych, a nawet wykluczających się, dyskursów pamięci o przeszłości. Pod koniec pierwszej dekady XXI wieku Katarzyna Bojarska, podsumowując liczne diagnozy powstające $\mathrm{w}$ ramach polskiej odmiany kultury posttraumatycznej $\mathrm{z}$ przełomu tysiącleci, stwierdziła:

Przez to, że brali w niej udział Polacy - świadkowie, ofiary, a niekiedy oprawcy (pośredni i bezpośredni) - sprawa jest bardziej skomplikowana, szczególnie dla pokoleń powojennych. Wchodzą one w posiadanie dziedzictwa, które nie jest ani jednoznaczne, ani chwalebne, natomiast wymaga rozliczenia i oceny, również krytycznej ${ }^{4}$.

\footnotetext{
2 M. Zaleski, Rozmowa żywych z umartymi, w tegoż: Echa idylli w literaturze polskiej doby nowoczesności i późnej nowoczesności, Kraków 2007, s. 46. Zaleski rozpoczyna rozważania od analizy znanego wiersza Tadeusza Borowskiego Sielanka, który „,antycypuje dyskusję nad (nie)obecnością umarłych w pooświęcimskim życiu, żarłocznie instalującym się na gruzach [...]. Dyskusję, która znajdowała zaczyn w ówczesnym wysypie wierszy stanowiących właśnie rozmowy z umarłymi. Dyskusję, która w końcu nie doszła do skutku - głównie jednak z powodów politycznych" [s. 33].

3 Tamże, s. 44.

4 K. Bojarska, Historia Zagłady i literatura (nie)piękna. "Tworki” Marka Bieńczyka w kontekście kultury posttraumatycznej, „Pamiętnik Literacki” 2008, z. 2, s. 93.
} 
Już u schyłku XX wieku, w warunkach rozpadu wszelkich mitów spajających wspólnotę, rozliczeń takich można było dokonywać jedynie jako jednostkowo przeprowadzane rozpoznania, czynione we własnym imieniu.

Narrator powieści Marka Bieńczyka zatytułowanej Tworki eksplicytnie ujawnia przyjętą perspektywę:

Przychodzę więc nawoływany, przesyłkę odbieram, własnym podpisem ten nieproszony, nieadresowany dar na tylu stronach kwituję i wołam was, bo może i z was ktoś przyjdzie, ktoś przybędzie na stałe do mojej ławeczki, wołam, tak, przyjedźcie najlepiej wszyscy w dowolnym czasie, który będzie się stawał, przyjedźcie ze wszech stron jakąkolwiek kolejką ${ }^{5}$.

Narrator stale wskazujący na swoją obecność we współczesnych Tworkach, niepozwalający zapomnieć o sobie piszącym opowieść o Soni na ławeczce w przyszpitalnym parku, wzywa jednocześnie: „czytajcie, czytajcie proszę, i święćcie imię wasze i pokwitujcie" ${ }^{6}$. Inaczej mówiąc - ujawnijcie własną kontrsygnaturę literackiej wizji. Tworki dzisiejsze stają się tym samym miejscem wielorako niejednorodnym: teraźniejszym i przeszłym, doświadczanym i utekstowianym, cudzym i własnym.

Podobnie rzecz się ma z Królowym Stojłem, pograniczną wsią będącą centrum wydarzeń w powieści Ignacego Karpowicza. W powstałej piętnaście lat po utworze Bieńczyka Sońce narrator w zdecydowanie większym stopniu, najczęściej autoironicznie, ujawnia kreacyjny wymiar opowieści:

muszę położyć nacisk na uniwersalny charakter tej historii, tej opowieści, którą przeczuwam, lecz której jeszcze nie poznałem. Ta historia musi być zrozumiała przede wszystkim dla innych, wtedy stanie się zrozumiała też dla mnie ${ }^{7}$.

Narracja o losach dotkniętej traumą wojenną Sońki szybko okazuje się relacją o jednoczesnym poznawaniu i przetwarzaniu jej losów, prowadzącym nie do zrozumienia przeszłości, lecz eksplikowania teraźniejszości i własnego w niej miejsca. Narrator-bohater wkracza w przestrzeń cudzą, która okazuje się na poły własną, niegdyś odrzuconą, dziś odzyskiwaną. W miarę rozwoju opowieści to właśnie gesty prowadzące do samopoznania kondycji twórcy okazują się nadrzędnym celem artystycznych działań.

Z kolei w wykreowanym przez Pawła Potoroczyna w Ludzkiej rzeczy niewielkim Piórkowie koegzystują już tylko niezliczone, mniej lub bardziej znane opowieści o czasie nieludzkim, a globalna katastrofa cywilizacyjna odbija się jak w soczewce w dziejach małej wiejskiej społeczności. Wszystko

\footnotetext{
5 M. Bieńczyk, Tworki, Warszawa 1999, s. 194.

6 Tamże.

7 I. Karpowicz, Sońka, Kraków 2014, s. 34.
} 
okazać się może „ludzką" - a więc zrozumiałą, możliwą do oswojenia i wyartykułowania sprawą; tym samym doświadczenia "czasu nieludzkiego" objawiają swój człowieczy wymiar, potoczny wizerunek i prosty, jakoby „ludowy" (wyrastający ze sfery ludowej moralności) osąd. W książce Potoroczyna bowiem najbardziej „ludzką rzeczą" okazuje się samo tworzenie narracji, ich powtarzanie, przekształcanie, dopasowywanie do własnych potrzeb. Nadmiar opowieści, nakładających się nie tylko palimpsestowo, ale i wielorako skrzyżowanych oraz wzajemnie dezawuujących swe prawdopodobieństwo - pozornie zakrywa, a w istocie paradoksalnie obnaża niemożność dotarcia do jakiejkolwiek "prawdy” o doświadczeniach wojny i Zagłady. Kompulsywnie mnożone historie lub ich możliwe do przekształcenia w obszerny tekst zawiązki ukazują stan niewiedzy maskowany przez świadomie wykorzystywane w utworze pokłady nawarstwiających się przez wiele dekad opowieści o przeszłości. Giorgio Agamben w tekście Ostatni rozdział historii świata stwierdził: „To, w jaki sposób czegoś nie wiemy, jest równie, a może i bardziej ważne od tego, w jaki sposób to coś znamy" ${ }^{8}$. Tym samym warunkiem, a zarazem kamieniem probierczym, wiedzy okazać się może zakreślanie granic strefy niewiedzy.

Narrator Ludzkiej rzeczy, mówiący wieloma głosami, zmieniający często rejestr swej wypowiedzi (odsłaniający skalę swoich możliwości) wskazuje niejednokrotnie na rolę świadomości kreacyjnej, wagę samego gestu artykułowania opowieści, zawierającego w sobie moc dookreślania tożsamości twórcy. Tekstowe sygnały znamionuje podobieństwo z tymi, które można odnaleźć w Sońce Karpowicza. Mowa w nich także o ocaleniu - jednak nie pamięci o przeszłości, lecz „ocalaniu siebie”. Kiedy narrator Sońki zdaje sobie sprawę, że musi „zapamiętać więcej” niż zostało opowiedziane, zaczyna rozumieć także, iż „musi pamięć zaprząc w teatralny lub powieściowy kierat, by siebie ocalić, by wreszcie opowiedzieć jakąś prawdę, zawalczyć o coś" 9 . Inaczej mówiąc, musi - jako przedstawiciel pokolenia niepamiętającego czasów okupacji - zamknąć traumatyczne doświadczenia wojenne w znany, oswojony kształt, a jednocześnie wytworzyć ocalający twórcę dystans i odsłonić piętra samoświadomości, także te aktualnie, równolegle z tworzeniem opowieści, dobudowywane.

Obaj narratorzy - i w Ludzkiej rzeczy, i w Sońce - zdają się więc po części powtarzać gesty narratora wykreowanego przez Bieńczyka w Tworkach. Ujawniane tam sygnały aktu tworzenia narracji o wojennych losach bohate-

8 G. Agamben, Ostatni rozdział historii świata, w tegoż: Nagość, przeł. K. Żaboklicki, Warszawa 2010, s. 126.

9 I. Karpowicz, Sońka, s. 59. 
rów zderzane są z gorzką świadomością ograniczeń wynikających z rzeczywistego przebiegu historycznych wydarzeń. Autor nie może uratować swych postaci od niechybnej śmierci - narrator zaś staje się medium tej przepełnionej bezsilnym żalem pewności. W Tworkach zostało stematyzowane pragnienie wkroczenia $\mathrm{w}$ granice cudzej przestrzeni - autokreacja pełni $\mathrm{w}$ nich rolę służebną. W Sońce tematyzowaniu podlegają reguły przepisywania cudzego losu dla własnych celów - przede wszystkim autokreacyjnych. W Ludzkiej rzeczy tematem pozostaje bezradność wobec nadmiaru opowieści o cudzych losach - kreacje postaci i autokreacja uzyskują ten sam status wyłącznie tekstowego, wielokrotnie zapośredniczonego literackiego bytu. Tym samym wskazane utwory przekształcają się w narracje nie tyle o końcu epoki i końcu świata, ile o ostatecznym kresie ocalającej, utrwalającej, pośredniczącej mocy tekstów kultury - kolejne z długiego szeregu literackie realizacje przekonań o ich immanentnej niezdolności wytwarzania czy przechowywania znaczeń.

W dotkniętej erozją i narażonej na ostateczny rozpad rzeczywistości, wszelkie afekty i emocje mogą być wyrażane jedynie przez istniejące $\mathrm{w}$ ludzkiej mowie nieadekwatne przybliżenia, ułomne metafory, nieskuteczne elipsy. W ten tylko sposób wypełnione może zostać zadanie twórczości ponowoczesnej, które można określić, za Ryszardem Nyczem, gromadzeniem dowodów (wrażeń, symptomów domysłów) na istnienie faktyczności. Faktyczność wyczuwalna jest poprzez opór, jaki stawia siłą swego bezwładu działaniom podmiotu oraz plastycznością swej substancji, jego władzom przedstawiania ${ }^{10}$. Negatywna obecność opierającej się uobecnieniu rzeczywistości dla sztuki ponowoczesnej staje się wyzwaniem, które może wypełniać w ograniczonym zakresie. Pozostaje zatem świadectwo jednostkowej woli poszukiwania i stawiania pytań, przy równoczesnym uznaniu niemożności dotarcia do zobiektywizowanych odpowiedzi i przekroczenia aktu samopoznania. Agamben, pisząc o braku przepisów na wyznaczanie sfery niewiedzy, wskazywał również, iż jej zakreślanie

nie oznacza po prostu niewiedzenia, nie chodzi tu jedynie o brak lub defekt. Przeciwnie - taka czynność oznacza utrzymanie właściwego związku z niewiedzą, zezwolenie na to, aby towarzyszyła ona naszym ruchom i kierowała nimi ${ }^{11}$.

10 R. Nycz, „Wyrażanie niewyrażalnego" w literaturze nowoczesnej (wybrane zagadnienia), w: Literatura wobec niewyrażalnego, red. W. Bolecki i E. Kuźma. Łódź 1998, s. 100. Badacz podkreślał w tym samym miejscu, iż dla ponowoczesnej twórczości „rzeczywistością byłoby przede wszystkim to, czemu modernizm odmówił właśnie istnienia: pozbawiona esencji materia realności; to, co bezkształtne, nieznaczne, nieznaczące, nieuchwytne."

11 G. Agamben, Ostatni rozdział historii świata, s. 127. 
W takiej perspektywie oglądu „związek z niewiedzą" można pojmować jako aktywną relację z tym, co niepoznawalne, a jednak dotkliwie obecne.

$\mathrm{W}$ powieści Bieńczyka szpital w Tworkach ukazany został jako przestrzeń niejednorodna: sceneria tragicznych wydarzeń sprzed półwiecza i współczesne miejsce pracy twórczej pisarza, próbującego nawiązać kontakt $\mathrm{z}$ przeszłością przez usytuowanie się $\mathrm{w}$ centralnym punkcie kreowanej (odnajdywanej, od-twarzanej) przez siebie historii. Katarzyna Bojarska podkreślała: „kluczowe w Tworkach są właśnie sama opowieść i pamięć oraz próba odtworzenia nieistniejącego świata z nędznych resztek, jakie po nim zostały" ${ }^{12}$. Akt pisania pojmowany jako akt przywracania utraconych miejsc, zatartych śladów, ulotnych pozostałości staje się działaniem wymagającym rzeczywistego zaangażowania - to z kolei wiąże się z pragnieniem, by także odbiorcy uznali konieczność wejścia w tryb uważnego, aktywnego, a zarazem emocjonalnego odbioru. Nade wszystko zaś, by autora i czytelników połączyło przekonanie o wspólnocie człowieczego losu, naznaczonego śmiertelnością i cierpieniem. Dlatego narrator powtarza: „sygnujcie na nowo, potwierdźcie, pokwitujcie, podpiszcie kiedyś odbiór, dorzućcie, wy wszyscy dziś niby imienni, swoje post, postscriptum" ${ }^{13}$.

Nie miała racji Aleksandra Ubertowska budując swoją krytyczną analizę na stwierdzeniu, iż Bieńczyk: „usunął poza horyzont swojej świadomości pisarskiej dramatyczne, determinujące sytuację pisarza Szoa napięcie między historią i fikcją, pomiędzy "zdarzyło się» i "opowiadam»"14. W Tworkach silne napięcie między historią a fikcją uwidacznia się właśnie na poziomie zderzania teraźniejszych reakcji opowiadającego z nieodwracalnym, wydobywanym z niepamięci przebiegiem minionych zdarzeń. Na przykład historia jednego z bohaterów, Jerzego o nieznanym nazwisku, ukrywającego się pod fałszywym mianem Marcelego Brochwicza, skłania narratora do pełnej bezsilności apostrofy: „No właśnie Marcelu Jerzy, powiedzmy Brochwicz, gdzie poszedłeś? Gdzieżeś, kurwa, przepadł? Wo bist du gegangen, gekommen i kaputt?"15. Bohater, zmęczony życiem w ciągłym strachu, zdecydował się, wraz z żoną i szwagierką, pójść do Hotelu Polskiego, w którym Niemcy zastawili pułapkę na ukrywających się jeszcze członków żydowskiej społeczności. Wyprawa, która musiała zakończyć się tragicznie, prowokuje narratora do wyznania:

\footnotetext{
12 K. Bojarska, Historia Zagłady i literatura (nie)piękna, s. 96.

13 M. Bieńczyk, Tworki, s. 194.

14 A. Ubertowska, Świadectwo - trauma - głos. Literackie reprezentacje Holocaustu, Kraków 2007, s. 295.

15 M. Bieńczyk, Tworki, s. 127.
} 
Marcelu Jerzy Brochwicz, weź sobie wszystko, co moje. Resztkę papierosa już zgasłego w cynowej popielniczce, tę butelkę whisky z czerwoną nalepką [...] bilet miesięczny na kolejkę, a z kuchni radio tranzystorowe, ze dwa co najmniej widelce, nóż, pieprz i sól. I weź sobie, tu obok, z tej ławeczki, komputer z polską czcionką, jak polski, psiakrew, dlaczego akurat Polski był wasz hotel, żebym tylko widział twoje ręce, jak go bierzesz i pakujesz, i twoje oczy, i twoje zęby, gdy się do mnie uśmiechasz ${ }^{16}$.

Pragnienie podarowania wielu zbędnych - i wówczas, i dziś - rzeczy jest w istocie wyrazem rozpaczy wywołanej przez niemożność zmiany biegu wydarzeń, konieczność uznania, iż zbrodnia z przeszłości pozostanie bezsensownym, okrutnym i nieodwracalnym mordem, także w świecie powieściowej fikcji.

Marek Zaleski wskazywał, iż tropy idylliczne w literaturze poświęconej Zagładzie służą wzmacnianiu zamierzonego efektu obcości: „zderzenie radykalnie anty-idyllicznego świata $\mathrm{z}$ toposem arkadyjskiego locus amoenus daje skutek podwójny: wydobywa okrucieństwo Holocaustu i nieprzystawalność doń literackiego przedstawienia"17. W powieści pozorna idylla ulega ostatecznemu zniszczeniu, giną też wszyscy przedstawieni jako piękni, dobrzy, barwni, radośni, a przede wszystkim niewinni. Na ruinach cywilizacji pozostają niezdarny grafoman Jurek i zdolna do mimikry „bezbarwna” Janka. Pozbawieni wyrazistych cech, odarci z właściwości, Adam i Ewa tkwią w opustoszałych ruinach, a ich utracony świat pozostanie miejscem niemożliwym do odtworzenia ani w rzeczywistości, ani w sferze sztuki. Celem artystycznych zabiegów stać się musi zatem odkrywanie i jednoczesne wytwarzanie tożsamości własnej, ustanawianej w relacji z minionym czasem i w odniesieniu do utraconych przestrzeni, trudne dążenie do samopoznania. Nasza tożsamość - jak przekonuje Zaleski - może być zakładnikiem opowieści:

To, co jest ostatecznym celem (obecność), w literaturze jest śladem (przedstawienie). Być to stawać się poprzez coraz to bardziej mnożące się znaki - ślady obecności. Im więcej znaków, tym silniejsze bycie. Powrót Soni dokonujący się w geście pisania jako pracy żałoby jest procesem wzrostu, przyrastania sensu, reintegracji własnej osobowości i tożsamości ${ }^{18}$.

\footnotetext{
16 Tamże, s. 128-129. Wyliczenie zbędnych podarunków kończy apostrofa: „Do Marcela Jerzego Brochwicza, do Marcela Jerzego Brochwicza palce moje i usta - chwała i cześć".

17 M. Zaleski, Jedyna instancja, w tegoż: Echa idylli, s. 277.

18 Tamże, s. 308. Zaleski podkreśla w zakończeniu, iż gdyby narrator miał oddać sprawiedliwość przeszłości, realiom Tamtego, dać im wyraz, musiałby wyjść poza język: „Poza przestrzeń języka, która jest przestrzenią ludzkiego. Lepiej pozostać w ludzkiej przestrzeni, zakończyć opowieść gestem afirmacji, niż zaciekle drążyć nieobecność: nigdy nie zdołamy oddać jej sprawiedliwości" [s. 310].
} 
Tworki zyskują tym samym status miejsca autobiograficznego, pozwalającego zamknąć w swoich granicach doświadczenie kreacji pojmowane jako gest przezwyciężania pustki i nicości, przekraczania głębokiej wyrwy między usuwaną w niepamięć przeszłością a naznaczoną utratą teraźniejszością.

Podobną drogę obrał Karpowicz, który reintegrację osobowości i tożsamości dokonującej się $\mathrm{w}$ akcie tworzenia uczynił osią swojego utworu. Pozostawił także liczne tropy pozwalające doszukiwać się w postaci Igora-Ignacego śladów autora. Równie często jak Tworki w powieści Bieńczyka pojawia się w Sońce nazwa miejscowa Królowe Stojło. Składająca się z czterech domostw wieś „na końcu świata” istnieje poza zasięgiem cywilizacji. Idylliczny z pozoru pejzaż przesłania jednak mroczną, naznaczoną śmiercią „istotę" krajobrazu. „Królewicz”, który znalazł się tam niezamierzenie, od początku wyczuwa ową niejednorodność przestrzeni:

Coś mu się boleśnie przypominało. Krajobraz wyglądał jak krajobraz, wszystko wyglądało, jak wyglądało, łąka i drzewa, mimo to cała ta przyroda, rzeka i niebo, droga i bociany, cała ta przyroda zawierała w sobie jakąś groźbę. Usiłował rozstrzygnąć, czy to groźba z przeszłości, czy może na przyszłość ${ }^{19}$.

Zapowiadana przez początkowe sceny opowieść o zderzeniu miejskiego z wiejskim, o przypadkowym spotkaniu niezdarnego mieszczucha z nieznającą świata wiejską starowiną, rozwija się zrazu w przewidywanym kierunku. Bohater wkracza w przestrzeń Sońki ostrożnie, z oporami, jakby przekraczał próg obcego świata. Wkrótce jednak udaje mu się „zadomowić”, a raczej odzyskać zdolność zadomowienia się w przestrzeni dzieciństwa, odrzuconej na progu dorosłego życia ${ }^{20}$. Niezobowiązująca pogawędka rychło zmienia się w mozolne odtwarzanie traumy przeszłości a zarazem relacjonowanie przebiegu aktu kreacji i wskazywanie piętrzących się na obranej drodze pułapek. $\mathrm{W}$ tym przypadku wierzchołkami fabularnego trójkąta $\mathrm{w}$ historii $\mathrm{z}$ przeszłości są młoda chłopka z polsko-białoruskiego pogranicza i jej kochanek esesman, który przekazuje jej wieści o zagładzie Żydów z Gródka, sąsiadów Sońki.

Zaznająca pierwszy raz w życiu miłości Sońka nie przestaje kochać tego, którego powinna odrzucić jako wroga, nawet pojmując rozmiar jego

\footnotetext{
19 I. Karpowicz, Sońka, s. 15-16.

20 Podjęcie rozmowy prowadzi w sposób naturalny do wspólnego posiłku, noclegu pod jednym dachem, wzajemnego wkraczania w granice intymności - jak choćby w scenie, w której Igor usiłuje uczesać resztkę włosów Sońki. Punktem kulminacyjnym musi okazać się samotne czuwanie warszawskiego reżysera nad konającą staruszką, która po wyartykułowaniu ostatniej spowiedzi może odejść, pozostawiając opowieść w rękach sprawnego rzemieślnika, wiedzącego, jak ją przekształcić, by wywołać pożądane reakcje publiczności.
} 
zbrodni. Justyna Sobolewska stwierdziła wprost: „nie da się dziś tak po prostu opowiadać takich historii, wszystko jest dyskursem, który można dowolnie kształtować. Narrator odsłania więc przed czytelnikiem całą machinę przekształcania cierpienia i śmierci we wzruszenie" ${ }^{21}$. Narrator jednoznacznie wyraża brak złudzeń - swój i nie zawsze tożsamego z nim bohatera-reżysera, przyzwyczajonego do manipulowania wzruszeniami odbiorców:

Czuł się jak kustosz w muzeum cudzych wspomnień, jak horolog przy rozłożonym mechanizmie. Dopiero, gdy się przełożyło te wspomnienia na własne doświadczenie, wyłaniało się coś zrozumiałego, jednocześnie jednak jasne stawało się to, że po drodze coś umykało. Autentyczność to jednak potworna klisza ${ }^{22}$.

Poszukiwanie śladów przeszłości, próba ich transpozycji okazuje się kolejnym zadaniem niemożliwym do wypełnienia - nawet przy sprzęganiu ich z materią własnych doświadczeń. Być może więc jedynym, co pozostaje, jest podejmowanie kolejnych prób relacyjnego ustanawiania jednostkowo negocjowanego, a przez to własnego miejsca w przepełnionej tekstami przestrzeni kultury. Jak się zdaje, Karpowicz uczynił tę wiedzę ośrodkiem swojego utworu, za cel zaś postawił sobie przekroczenie implikowanych przez nią ograniczeń, artystyczne przezwyciężenie ułomności reprezentacji.

Zamiar Piotra Potoroczyna można z kolei odczytać jako podjęcie gry z konwencjami, świadomie rozgrywanej na płaszczyźnie przede wszystkim intertekstualnej. Prowadzić on może jednak do postrzegania utworu jako rezultatu strategii służącej wytwarzaniu dzieł przynależących do "prozy środka". Literackie realizacje tego rodzaju oferują czytelnikom mniej wymagającym przekonanie, iż obcują z twórczością wyrastającą ponad przeciętną produkcję rynku książek. Odbiorcom o większych oczekiwaniach autorzy oferują sygnały świadomego naruszania tradycyjnych ujęć, przełamywania stereotypowych realizacji, przestawiania i autorskiego montażu osadzonych w potocznej świadomości obrazów. Ślady przeszłości ulegają wówczas ujednoliceniu - jako elementy tekstowych gier - niezależnie od swej proweniencji.

Koncepcje śladu, definiujące pojęcie jako formę obecności tego, co minione, zapomniane, wymykające się przedstawieniu lub utracone, wskazują

21 J. Sobolewska, Zdrajczyni, dziwka, szeptucha, „Polityka” nr 2958, 14.05.2014, s. 80. Badaczka zastanawia się nad skutkami obranej strategii w perspektywie odbioru: „to może być drażniące, bo czytelnik nie wie miejscami, czy kadysz pojawia się, bo żydowskość jest trendy, czy jest koniecznym i jedynym możliwym pojednaniem (uczestniczą w nim ofiary i oprawcy)".

22 I. Karpowicz, Sońka, s. 108. 
nie tylko na związki śladu z kategorią pamięci jednostkowej czy zbiorowej, ale i na jego immanentną niekoherencję oraz permanentną niestabilność. Utrwalane mimo to w niezliczonych tekstach kultury zdradzają wówczas swą podatność na zawłaszczanie w ramach rozmaitych dyskursów i tendencję do zastygania w doraźnie przydatnych kształtach ${ }^{23}$. Kolejne literackie realizacje tematów, których zadaniem jest restytucja lub rewindykacja śladów przeszłości, zdają się z reguły zaspokajać przede wszystkim pisarskie pragnienie emulacji. Narrator Ludzkiej rzeczy z pozoru dąży do zgłębienia historii fikcyjnego Piórkowa i jego mieszkańców oraz do jej odtworzenia w kształcie, który pozwoliłby dotrzeć do egzystencjalnej prawdy czy choćby prawdopodobieństwa zdarzeń rozgrywających się na peryferiach wielkiej wojny, doświadczeń pozostających poza nurtem głównych wydarzeń historycznych. Opowiada raz jeszcze, by obnażyć dystans, nieuchronnie towarzyszący wyprawom w przeszłość i jego współczesną specyfikę.

Wyraziście dookreślane medium opowieści drwi z twórców wszelkiego rodzaju, przekonując, iż "towarzystwo artystów”, które łże jak najęte, to mitomani i patologiczni kłamcy, trudniący się przesłanianiem "prawdy":

Muszą tej prawdzie koniecznie dopisać rymy, rytmy i harmonie, dorysować perspektywę, drugie dno, trzeci i czwarty plan, wijącą się drogę w prawym górnym rogu, wykoncypować nieskończoność, z czegoś, co nawet porządnie zacząć się nie chce... Musi toto koniecznie powiedzieć, co wypowiedzieć się nie da... [...] A jakie niezdolne... I gotowe zabić za talent... ${ }^{24}$

Jednak przy bliższym oglądzie krytyka zawarta w rozważaniach stylizowanych na wypowiedź wyrastającą ze zdroworozsądkowych przekonań czy owej "ludowej mądrości" jest sygnałem wyrazistej ironii (i autoironii). Narrator stwierdza na przykład: „W Białobrzegach żyły trzy rodzaje Żydów heroiczni, hedoniczni i paniczni" [s. 42], próbując rzekomo przybliżyć nieusuwalne podziały w łonie żydowskiej wspólnoty ${ }^{25}$. Proste uporządkowanie zdradza jednak już swym językowym kształtem sztuczność i przyjętą

23 Zob. Modi memorandi. Leksykon kultury pamięci, red. M. Saryusz-Wolska, R. Traba, Warszawa 2014. W szczególności hasła: A. Zawadzki, Ślad; M. Marszałek, Świadectwo; P. T. Kwiatkowski, Niepamięć.

24 P. Potoroczyn, Ludzka rzecz, Warszawa 2013, s. 207. Dalej w tekście numery stron przy cytatach według tego wydania.

25 Ten fragment opowieści odwzorowuje trzy funkcjonujące jeszcze przed wojną stereotypowe wyobrażenia żydowskich wyborów tożsamości: „Heroiczni trudzili się szyciem ubrań i butów, leczeniem zębów, pisaniem podań i wyszynkiem, chodzili do synagogi, kochali dzieci. Paniczni chrzcili się i wyjeżdżali byle dalej, w asymilację pełną pogardliwych spojrzeń i samotnych wigilii bez kolęd. Hedoniczni gadali o rewolucji, palili papieroski, patrzyli na Moskwę albo marzyli o Palestynie" [tamże, s. 42]. 
w utworze perspektywę rzutowania wstecz rozpoznań przynależących do późniejszych epok. Podobnie rzecz się ma z konkluzją: „Kto to mógł wiedzieć, że i ci, i tamci, nie cierpiąc się i wrzeszcząc, biegali dookoła komina?" [s. 42]. Ważną postacią w utworze jest nieudolny literat, marzący o wydaniu sonetów, pragnący sławy i licznego grona czytelników-wielbicieli jego talentu. Jednak dziedzic Radecki pozostaje twórcą niespełnionym, bowiem dotknięty został artystyczną ułomnością - nie wiedząc, kim jest, nie jest w stanie wyrazić siebie. W przypadku prozy Pawła Potoroczyna niewiedza - czy inaczej wiedza o niemożności rzeczywistego zinterioryzowania cudzego doświadczenia - skutkuje owym nadmiarem, uruchomianiem nadmiaru opowieści o wyraźnie literackiej proweniencji. Przywoływane teksty, jak i poszczególne ich elementy poddawane są swoistej hiperbolizacji służącej ujawnianiu gry z tradycją na wszelkich poziomach utworu. Przebieg akcji powieści wyznacza msza pogrzebowa odprawiana w intencji chłopskiego dowódcy oddziału partyzanckiego Jasia Smyczka, którego pochówku zabronili Niemcy pod groźbą surowych represji. Msza stanowi pretekst do odtworzenia losów nie tylko chorążego i członków jego oddziału, ale także wskazaniu rodowodów i biografii wszystkich uczestników pogrzebu. Sam Smyczek to ciało w trumnie, a mimo wszystko główny bohater utworu ${ }^{26}$. W Ludzkiej rzeczy ujawniany jest nieustannie mitotwórczy charakter opowieści oraz okoliczności rodzenia się legendy dzielnego partyzanta - tym samym kwestia prawdopodobieństwa zostaje uchylona ${ }^{27}$. Tak samo rozwiązana została sprawa jego genealogii - ma w sobie krew nie tylko francuską i austriacką, ale nawet indiańską - a przynależy raczej do świata mitycznych półbogów i herosów niż "zwykłych ludzi".

Drobiazgowo zostały odtworzone w powieści skomplikowane rodowody potomków napoleońskiego oficera Radeckiego oraz dziedziczenia przez nich skromnego majątku w prowincjonalnym Piórkowie ${ }^{28}$ - dochodzi tu do wyrazistego przerysowania możliwych tylko hipotetycznie biografii. Jeden z bohaterów podczas pobytu w Ameryce Północnej najpierw poślubia Mulatkę, później Indiankę, doprowadzając tym samym do rozdzielenia dwóch gałęzi rodu. Dziedzic Radecki pozna swego bliskiego kuzyna Jana Smyczka do-

\footnotetext{
26 Postać Smyczka zdradza liczne podobieństwa z bohaterem powieści Wiesława Myśliwskiego - zob. W. Myśliwski, Kamień na kamieniu, Warszawa 1984.

27 Ważnym kontekstem w interpretacji Ludzkiej rzeczy jest także twórczość Tadeusza Nowaka, przede wszystkim jego prozatorskie opowieści zawarte w tomie Pótbaśnie (Warszawa 1976).

28 Przebieg zdarzeń skłania do porównań z powieścią Kazimierza Brandysa - zob. K. Brandys, Wariacje pocztowe, Warszawa 1972. Można odnaleźć także paralele biografii postaci z życiorysami później wykreowanych szwoleżerów napoleońskich, bohaterów Warunku Eustachego Rylskiego (Warszawa 2005).
} 
piero po powrocie do Piórkowa, a dowie się o pokrewieństwie, kiedy obaj trafią do jednego partyzanckiego oddziału. W Piórkowie zresztą większość postaci zdaje się być ze sobą mniej lub bardziej jawnie spokrewniona, choć nie zawsze są świadome tego faktu - przyrodnimi braćmi okazują się, nic o tym nie wiedząc, także proboszcz katolickiej parafii Morga (nieznający nadto swych żydowskich korzeni) oraz luteranin z austriackim paszportem, właściciel i woźnica jedynego w okolicy karawanu, Kazimierz Melus.

W Ludzkiej rzeczy szlachecki ród Radeckich wygasł ostatecznie w czasie wojny. Japońska żona dziedzica wychowywała dwóch synów tak, że jeden $\mathrm{z}$ nich zginął pod Stalingradem w mundurze hitlerowskiego żołnierza, drugi poświęcił swoje życie w obronie Cesarstwa Japonii, stając się lotnikiem-kamikadze w dalekiej Azji. Natomiast jedyne dziecko Smyczka (określone na nagrobku jako "Smyczę bez imienia”) urodziło się martwe, ale tylko ono z tego pokolenia zostało pochowane na piórkowskim cmentarzu. Schyłek swego pozbawionego sensu życia ostatni Radecki spędził już nie jako dziedzic, ale rezydent $\mathrm{w}$ uwłaszczonym pałacu. $\mathrm{W}$ połączeniu, a zarazem starciu tradycji szlacheckiej i chłopskiej czy raczej powtórzonym geście podjęcia gry z dziedzictwem kultury szlacheckiej i chłopskiej prymat oddany został żywiołowi plebejskiemu, jakoby bardziej autentycznemu, zdrowemu, naturalnemu. Widoczne jest to także $\mathrm{w}$ ramach rozbudowanej sfery erotycznej utworu: seksualne doświadczenia bohaterów wywodzących się z warstwy określanej jako niższa okazują się z reguły doznaniem niezwykle silnym, wszechogarniającym, nieprzezwyciężalnym, tym bardziej, że zestawione zostały z po części pozorowanymi, po części perwersyjnymi przygodami erotycznymi przedstawiciela tak zwanej ",klasy wyższej”.

W powieści Potoroczyna świadomość uwięzienia w sieci zapożyczeń jest nieustannie czy wręcz natrętnie ujawniana. Narrator wyraża swą wiedzę na rozmaite sposoby, nieraz wprost, jakby dając odpór mogącym się nasuwać w trakcie lektury wątpliwościom: „Bo to wszystko jest kradzież, cała ta sztuka to jedno wielkie złodziejstwo. Każdy kradnie od każdego, kradną, co popadnie, a bezwstydnie... Kleptomuzyka... Kleptosztuka... Kleptoliteratura..." Z pułapki powtórzeń nie ma już jednak wyjścia, bowiem ,jjak się trafi taki, co nie kradnie, to znaczy, że nic nie czyta, nie słucha i nie ogląda. Z obawy, żeby nie być posądzonym o kradzież, stacza się w ignorancję i ciemnotę" [s. 208]. Taki "kleptofob” okazuje się zatem bardziej nieautentyczny niż jego zarażeni powszechną kleptomanią adwersarze, fałszując własne miejsce $\mathrm{w}$ kulturze. Natomiast uderzająca konsekwencja, z jaką w utworze powtarzane są gesty „kleptomańskiej” samoświadomości uzmysławia, iż konstrukcja narratora służyć ma przede wszystkim stworzeniu alibi dla autora, uprzedzającego mogące pojawić się wątpliwości i uwagi krytyczne. 
Narrator stwierdza też z przekonaniem: „Tylko kreacja, kłamstwo i nadpodaż są specyficznie człowiecze, cała reszta, te popędy, te instynkty, te psychologie, wszystko występuje w przyrodzie" [s. 209]. Jednak żaden akt kreacji, będący w mniejszym lub większym stopniu zmyśleniem, przeinaczeniem, przetwarzaniem istniejących fikcji nie jest zdolny przeciwstawić się ciszy, niweczącej wszelkie ludzkie wysiłki przekroczenia egzystencjalnych ograniczeń. Narrator tak określa jej przemożną siłę: „ciszy przed biblijnym potopem nie rozproszy żadna modlitwa, ciszy pogorzeliska nie przekupi najszczersza skrucha podpalacza, ciszy martwego noworodka nie wygonisz, bo nie ma takiego precz, do którego mogłaby pójść" [s. 127]. Grobowa cisza zalega nad losem Hahama Gieskanera, białobrzeskiego Żyda, który stracił dom, majątek, żonę i wszystkich swoich synów, a więc kiedy przyłączył się do oddziału partyzanckiego został niejako skazany na uznanie za swój pseudonim, za nowe miano, imienia biblijnego Hioba. Tenże Hiob, jedyny Żyd, który nie mógł umrzeć, choć nieustannie igrał ze śmiercią, z woli autora musiał także przejść scenę bezsilnego złorzeczenia Bogu i ludziom - ale w jego historii żadna strata nie doczekała się zadośćuczynienia.

Ciszę można, co prawda, próbować wyrazić słowami z książki, którą nastoletni Deleś Gieskaner, jedyny pozornie ocalony syn Hahama (bo „na czas” przechrzczony na Adasia Zajonca), zabrał ze sobą w plecaku i czytał współtowarzyszom niedoli z klasztornego sierocińca: „Przed burzą bywa chwila cicha i ponura / Kiedy nad głowy ludzi przeleciawszy chmura / Stanie i grożąc twarzą, dech wiatrów zatrzyma" [s. 187]. Poezja stworzona przez wieszcza nie wpłynęła jednak na los młodego potomka białobrzeskich Żydów, nie wskazała mu drogi. Deleś po ucieczce z sierocińca trafił do powiatowego posterunku Urzędu Bezpieczeństwa, by w wieku dziewiętnastu lat zostać jego komendantem - tekst szlacheckiego eposu pozostał dla niego (i wielu innych) jedynie milknącym, unieważnionym przez późniejsze doświadczenia, wspomnieniem. Powieść Potoroczyna dowodzi ostatecznie, że gesty niewiedzy i artykulacja milczenia mogą paradoksalnie konstytuować się $\mathrm{w}$ nadmiarze słów, cytatów, literackich odwołań i przetwarzanych opowieści. Utwór kończy retoryczne, choć spodziewane pytanie: „Skąd ta cisza?".

Ironia i autoironia, często też podszyty goryczą sarkazm $\mathrm{z}$ reguły towarzyszą twórcom udającym się na literackie wyprawy do miejsc z nieodległej przeszłości, a jednak ostatecznie utraconych, startych z powierzchni ziemi, pozostających cudzą przestrzenią, niemożliwych do odzyskania w opowieści. Eksploracja tych miejsc prowadzi dziś niejednokrotnie do zastąpienia prezentacji tego, co musi pozostać cudze i trudne do oswojenia, wyrazistymi gestami samopoznania, rodzącego się w akcie twórczym. Projekt artystycz- 
nego zawłaszczania obcych przestrzeni może przeradzać się w rozpoznawanie wszelkich ograniczeń pisarskiej swobody kreacyjnej, jednak tryb ich przekraczania, próby artystycznego przezwyciężenia oporu materii realności (przeszłej i teraźniejszej) uobecniane $\mathrm{w}$ tekstach pozostają ich niezbywalną wartością.

\section{In Other Spaces - Narrative Gestures of (Self)Recognition in Selected Literary Works at the Turn of the Centuries}

\section{Summary}

The article attempts to recognize the most distinctive aspects of spatial representations in literary works from the 20th and 21st centuries. It analyzes the narrative strategies employed in the following novels Terminal by Marek Bieńczyk, Sońka by Ignacy Karpowicz and Ludzka rzecz by Paweł Potoroczyn. Consequently, it shows that textual exploration of space which is foreign, other, untameable may be instrumental in authorial self-representation and that it may additionally reveal the writing process with its innate limitations.

Keywords: literary space, representation, narrative strategies, Marek Bieńczyk, Ignacy Karpowicz, Paweł Potoroczyn 